\title{
Coordination Chemistry and Asymmetric Catalysis with a Chiral Diphosphonite
}

\author{
Jarl Ivar van der Vlugt, ${ }^{[a]}$ Jos M. J. Paulusse, ${ }^{[a]}$ Eric J. Zijp, ${ }^{[a]}$ Jason A. Tijmensen, ${ }^{\text {[a] }}$ \\ Allison M. Mills, ${ }^{[b]}$ Anthony L. Spek, ${ }^{[b]}$ Carmen Claver, ${ }^{[c]}$ and Dieter Vogt*[a]
}

Keywords: Diphosphonite compounds / Asymmetric hydrogenation / Palladium / Rhodium / Asymmetric hydroformulation / Enantioselectivity

\begin{abstract}
The improved synthesis of the chiral diphosphonite, XantBino (1), based on a xanthene backbone and bearing chiral binaphthyl groups on both $\mathrm{P}$-atoms is described together with its $\mathrm{Pd}^{\mathrm{II}}$ and $\mathrm{Rh}^{\mathrm{I}}$ complexes. The ${ }^{31} \mathrm{P}$ NMR spectra of both complexes point out that the two phosphorus atoms are chemically inequivalent. The complex cis-[ $\left.\mathrm{PdCl}_{2}(\mathbf{1})\right](\mathbf{2})$ is structurally characterized by NMR spectroscopy and X-ray crystallography. The molecular structure reveals an unusually small bite angle for this member of the xantphos family of only $100^{\circ}$. The rhodium-catalyzed asymmetric hy-
\end{abstract}

droformylation of styrene and vinyl acetate as well as the asymmetric hydrogenation of methyl (Z)-2-acetamidocinnamate, applying this chiral diphosphonite 1, are described. Low enantiomeric excesses are obtained in the asymmetric hydroformylation, while use of the catalyst precursor $[\mathrm{Rh}(\mathrm{cod})(\mathbf{1})] \mathrm{BF}_{4}(\mathbf{3})$ results in a promising enantiomeric excess in the Rh-catalyzed asymmetric hydrogenation.

(C) Wiley-VCH Verlag GmbH \& Co. KGaA, 69451 Weinheim, Germany, 2004)

\section{Introduction}

The rhodium-catalyzed asymmetric hydroformylation of vinylarenes, with styrene as a model substrate, using rhodium-based catalysts, is a typical benchmark reaction for the comparison of new catalyst systems. ${ }^{[1]}$ A number of ligand classes have been applied in this reaction, aiming at a thorough understanding of both the kinetics and the origin of enantioselectivity, for example, diphosphanes, ${ }^{[2]}$ phosphane-phosphites, ${ }^{[3]}$ diphosphites, ${ }^{[4]}$ aminophosphane-phosphinites, ${ }^{[5]}$ aminophosphanes, ${ }^{[6]}$ and other bifunctional systems. ${ }^{[7]}$ However, only few catalytic systems show satisfactory enantioselectivity for the desired branched aldehyde, with BINAPHOS $\left(\mathbf{L}_{\mathbf{1}}\right)$ as the current benchmark ligand in many respects (Figure 1). Phosphonites have been largely overlooked in homogeneous catalysis to date. Recently, some reports have appeared on diphosphonites in asymmetric hydrogenation ${ }^{[8]}$ as well as in hydroboration, ${ }^{[9]}$ making use of several backbones. Next to this, monophosphonites have attracted some attention, especially for the asymmetric

[a] Schuit Institute of Catalysis, Laboratory of Homogeneous Catalysis, Eindhoven University of Technology,

P. O. Box 513, $5600 \mathrm{MB}$ Eindhoven, The Netherlands

[b] Laboratory for Crystal and Structural Chemistry, Department of Chemistry, Utrecht University,

Padualaan 8, $3584 \mathrm{CH}$ Utrecht, The Netherlands

[c] Departament de Química Física i Inorgànica, Universitat Rovira i Virgili,

Pl. Imperial Tàrraco 1, 43005 Tarragona, Spain

Fax: (internat.) + 31-40-2455054

E-mail: d.vogt@tue.nl hydrogenation of enamides, ${ }^{[8 c]}$ the copper-catalyzed addition of diethylzinc to enones, ${ }^{[10]}$ and the hydroformylation of octenes. ${ }^{[11]}$ Little precedent exists on the application of (chiral) diphosphonites in the transition metal catalyzed hydroformylation of alkenes or vinyl arenes. Dahlenburg and coworkers reported on chiral dialkyl-derived diphosphonites $\mathbf{L}_{2}$, their platinum complexes, and the Pt/Sn-catalyzed hydroformylation of styrene, but only very low enantioselectivities were obtained. ${ }^{[12]}$ The groups of Schmutzler and Börner published a joint study on calix[4]arene-based achiral diphosphonites $\mathbf{L}_{\mathbf{2}}$ in the Rh-catalyzed hydroformylation of terminal alkenes. The regioselectivities remained well below 2 , indicating only monodentate behavior of these ligands systems. ${ }^{[13]}$

We have previously reported on the use of chiral xanthene-based diphosphonites in the asymmetric hydrocyanation of vinyl arenes that showed good enantioselectivities of up to $63 \%$ for 4 -isobutylstyrene. ${ }^{[14]}$ We recently published on the synthesis and use of sterically constrained achiral diphosphonites $\mathbf{L}_{\mathbf{4}}$ in the rhodium-catalyzed hydroformylation of alkenes and showed that these systems are wellsuited for the conversion of 2-butene into $n$-pentanal. ${ }^{[15]}$ Together with our studies on the coordination chemistry of these xanthene-derived diphosphonites towards various transition metals, ${ }^{[16]}$ this prompted us to explore the potential of chiral diphosphonite $\mathbf{1}$ in various asymmetric catalytic reactions. In this paper we report on the improved synthesis of compound $\mathbf{1}$, its coordination with palladium and 
<smiles>C1=C2OP(Oc3ccc4ccccc4c3-c3c(-c4cccc5ccccc45)ccc4ccccc34)C=C2C(c2c(-c3ccccc3)ccc3ccccc23)=c2ccccc2=C1</smiles><smiles>OP(Oc1ccccc1)C1CCCC1P(Oc1ccccc1)Oc1ccccc1</smiles><smiles>CO[C@H]1CC[C@H](OP2Oc3ccccc3-c3ccccc32)OP1Oc1ccccc1-c1ccccc1</smiles>

$\mathbf{L}^{3}$<smiles>[R]c1ccc(OP(Oc2ccc([R])cc2[R])c2cc([R])cc([X])c2Oc2c([X])cc([R])cc2P(Oc2ccc([R])cc2[R])Oc2c([R])cc([R])cc2-c2cc([R])cc([R])c2O)c([R])c1</smiles>

Figure 1. Representation of several reported literature ligand systems: $\mathbf{L}_{\mathbf{1}}$ ) Nozaki's BINAPHOS; $\mathbf{L}_{\mathbf{2}}$ ) cyclopentane-based diphosphonites by Dahlenburg; $\mathbf{L}_{3}$ ) calix[4]arene-derived diphosphonite of Schmutzler and Börner (the ellipsoid represents a $p$-tert-butylcalix[4]arene unit); $\mathbf{L}_{\mathbf{4}}$ ) our own sterically constrained achiral diphosphonites

rhodium, and the use of this ligand in the rhodium-catalyzed asymmetric hydroformylation of styrene and vinyl acetate and in the asymmetric hydrogenation of methyl $(Z)$ 2-acetamidocinnamate (Figure 2).

\section{Results and Discussion}

\section{Synthesis of Diphosphonite 1 and Its Dichloropalladium Complex 2}

Diphosphonite 1 was prepared in a straightforward manner, using a two-step procedure, as illustrated in Scheme 1. The [bis(diethylamino)]diphosphonite was derived from the commercial starting material 9,9-dimethylxanthene in mod-

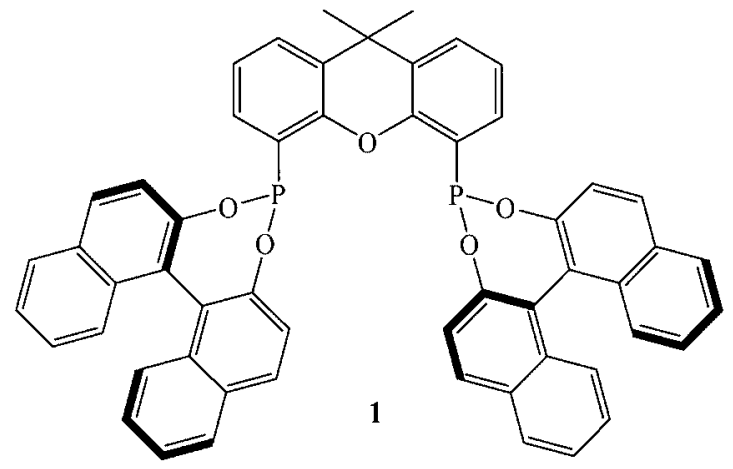

Figure 2. Chiral xanthene-based diphosphonite used in this study

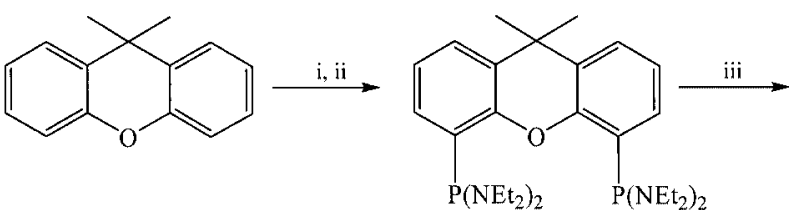

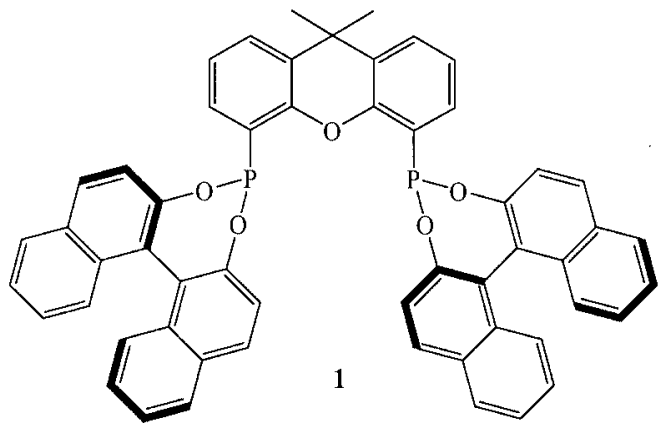

Scheme 1. Synthetic route to compound 1: i) $n \mathrm{BuLi}, \mathrm{TMEDA}$, $\mathrm{Et}_{2} \mathrm{O},-40^{\circ} \mathrm{C}, 16 \mathrm{~h}$; ii) $\mathrm{ClP}\left(\mathrm{NEt}_{2}\right)_{2}$, pentane, $-60^{\circ} \mathrm{C}, 16 \mathrm{~h}$.; iii) $2,2^{\prime}-$ dihydroxy-1,1'-binaphthyl ( 2 equiv.), toluene, tetrazole, $\Delta T, 1$ day

erate to good yield. ${ }^{[14]}$ Subsequently, the chiral binaphthyl groups were introduced to obtain the desired chiral diphosphonite. This reaction is catalyzed by tetrazole as protonation agent, which is a slight but important modification of the literature procedure. Addition of tetrazole shortened the reaction time considerably, analogous to the synthesis of sterically constrained diphosphonites previously reported by our group. ${ }^{[15]}$ The pure compound was obtained by layering a solution of the crude product in dichloromethane with acetonitrile. This was omitted in the earlier methodology. In general, the second step led to an unwanted sideproduct $(<10 \%)$, most likely the monophosphonite, which justified the crystallization step. The ${ }^{31} \mathrm{P}$ NMR spectrum of the pure compound showed a singlet at $\delta=178.0 \mathrm{ppm}$, which seems remarkably low-field, even for a phosphonite moiety. This value reflects the fact that both electronic factors as well as conformational constraints strongly affect the chemical shift of the ${ }^{31} \mathrm{P}$ nucleus.

We were interested in the detailed coordination behavior of XantBino (1) towards palladium and rhodium. Previously, only the bischelate $\mathrm{Ni}(\mathbf{1})_{2}$ was described. ${ }^{[14]}$ From the reaction of $\mathrm{PdCl}_{2}(\mathrm{cod})$ with ligand $(R, R)-\mathbf{1}$ at room temperature, a yellow compound was obtained, for which the ${ }^{31} \mathrm{P}$ NMR spectrum shows two doublets at $\delta=143.1 \mathrm{ppm}$ 
and $137.4 \mathrm{ppm}$. The observed coupling constant $J_{\mathrm{P}-\mathrm{P}}$ is $46.5 \mathrm{~Hz}$, apparently indicating that the phosphorus atoms are chemically inequivalent. This is attributed to the chiral, bulky binaphthyl units. From the ${ }^{1} \mathrm{H}$ NMR spectrum, it appears that the methyl groups in the backbone are also inequivalent, indicating that the aromatic skeleton of the xanthene is bent. ${ }^{[14,17]}$

Single crystals suitable for X-ray analysis were grown by layering a dichloromethane solution of complex 2 with acetonitrile. The molecular structure of $c i s-\left[\mathrm{PdCl}_{2}(\mathbf{1})\right]$ is presented in Figure 3, together with selected bond lengths and angles. It is evident that ligand $\mathbf{1}$ acts as a bidentate ligand, coordinating in a cis-fashion to the palladium atom.

The coordination around the central palladium atom is distorted square-planar, with a $\mathrm{P}^{1}-\mathrm{Pd}-\mathrm{P}^{2}$ angle of 99.99(3) ${ }^{\circ}$, while the $\mathrm{Cl}^{1}-\mathrm{Pd}-\mathrm{Cl}^{2}$ angle is $90.15(4)^{\circ}$. There are few examples on palladium diphosphonite complexes known in literature. However, the bond lengths for $\mathrm{Pd}-\mathrm{P}$ $\left[\mathrm{Pd}-\mathrm{P}^{1}\right.$ is $2.2449(9) \AA$ and $\mathrm{Pd}-\mathrm{P}^{2}$ is 2.2532(9) $\left.\AA\right]$ and $\mathrm{Pd}-\mathrm{Cl}\left[\mathrm{Pd}-\mathrm{Cl}^{1}\right.$ is $2.3412(10) \AA$ and $\mathrm{Pd}-\mathrm{Cl}^{2}$ is $2.3442(9)$ $\AA$ A] are normal, in agreement with those found by Agbossou ${ }^{[18]}$ and Schmutzler. ${ }^{[19]}$ Compared with crystal structures of Pd complexes known for xanthene diphosphane ligands, the bite angle of $100^{\circ}$ for ligand $\mathbf{1}$ is unusually small. For instance, we previously reported on trans-coordinated diphosphonites ${ }^{[16]}$ and both van Leeuwen et al. ${ }^{[20]}$ and Buchwald et al. ${ }^{[21]}$ reported on trans-Pd(Xantphos) complexes. Only in the case of $\mathrm{Pd}^{0}$ complexes or with cationic palladium species has cis-coordination of Xantphos been ob- served by X-ray crystallography. ${ }^{[20,22]}$ In complex 2 , the angles $\mathrm{Pd}-\mathrm{P}^{1}-\mathrm{C}^{41}$ and $\mathrm{Pd}-\mathrm{P}^{2}-\mathrm{C}^{54}$ were $109.87(11)^{\circ}$ and $108.57(12)^{\circ}$, respectively (Figure 4$)$. The dihedral angle between the metal plane $\mathrm{Cl}^{1}-\mathrm{Pd}-\mathrm{Cl}^{2}$ and the ligand plane $\mathrm{P}^{1}-\mathrm{P}^{2}-\mathrm{C}^{41}$ is $115.7^{\circ}$, indicating that the palladium is actually positioned outside the plane defined by the backbone and the phosphorus atoms, as illustrated in This is quite unusual for cis-Pd-diphosphorus complexes. A similar structural disposition of the metal atom, together with a small ligand bite angle, was found for an unexpected ortho-

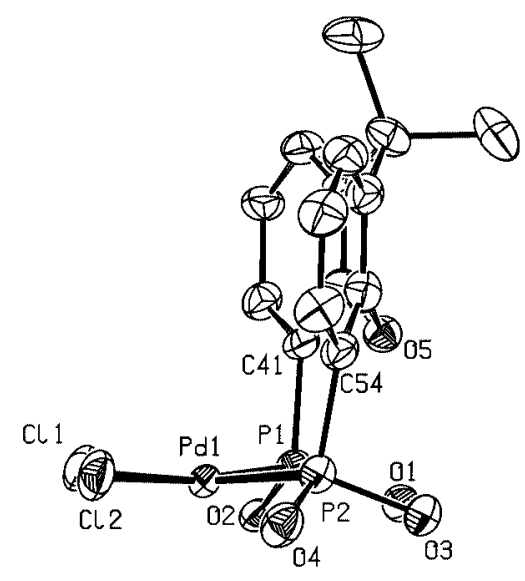

Figure 4. Illustration of the geometry around the square-planar palladium atom in complex $\mathbf{2}$, showing the dihedral angle between the metal plane and the ligand plane

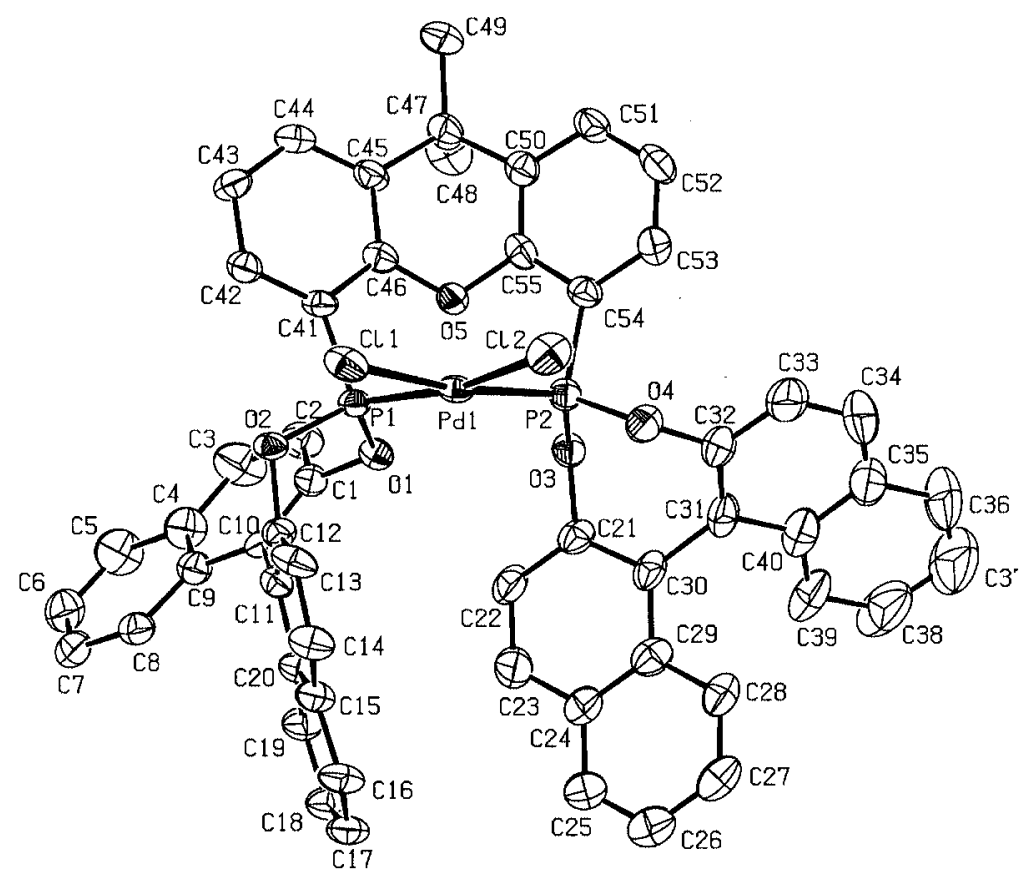

Figure 3. ORTEP representation of complex 2, cis- $\left[\mathrm{PdCl}_{2}(\mathbf{1})\right]$; displacement ellipsoids are drawn at the 50\% probability level; all hydrogen atoms and solvent molecules are omitted for clarity; $\mathrm{Pd}-\mathrm{P}^{1} 2.2449(9) ; \mathrm{Pd}-\mathrm{P}^{2} 2.2532(9) ; \mathrm{Pd}-\mathrm{Cl}^{1} 2.3412(10) ; \mathrm{Pd}^{2}-\mathrm{Cl}^{2} 2.3442(9) ; \mathrm{P}^{1}-\mathrm{O}^{1}$ 1.613(2); $\mathrm{P}^{1}-\mathrm{O}^{2} 1.601(2) ; \mathrm{P}^{2}-\mathrm{O}^{3} 1.800(3) ; \mathrm{P}^{2}-\mathrm{O}^{4} 1.604(3) ; \mathrm{P}^{1}-\mathrm{C}^{41} 1.800(3) ; \mathrm{P}^{2}-\mathrm{C}^{54} 1.815(3) ; \mathrm{O}^{5}-\mathrm{C}^{46} 1.380(4) ; \mathrm{O}^{5}-\mathrm{C}^{55} 1.388(4) ;$ $\mathrm{Pd}-\mathrm{O}^{5}$ 3.284(2); $\mathrm{P}^{1}-\mathrm{P}^{2}$ 3.4455(12); $\mathrm{Cl}^{1}-\mathrm{Pd}-\mathrm{Cl}^{2}$ 90.15(4); $\mathrm{P}^{1}-\mathrm{Pd}-\mathrm{P}^{2}$ 99.99(3); $\mathrm{Cl}^{1}-\mathrm{Pd}-\mathrm{P}^{1}$ 82.70(3); $\mathrm{Cl}^{1}-\mathrm{Pd}^{2}-\mathrm{P}^{2} 172.15(3) ; \mathrm{Cl}^{2}-\mathrm{Pd}^{2}-\mathrm{P}^{1}$ 170.01(3); $\mathrm{Cl}^{2}-\mathrm{Pd}-\mathrm{P}^{2} 86.23(3) ; \mathrm{O}^{1}-\mathrm{P}^{1}-\mathrm{O}^{2} 102.46(12) ; \mathrm{O}^{3}-\mathrm{P}^{2}-\mathrm{O}^{4} 103.07(13) ; \mathrm{Pd}-\mathrm{P}^{1}-\mathrm{O}^{1} 116.50(9) ; \mathrm{Pd}-\mathrm{P}^{1}-\mathrm{O}^{2} 117.78(9) ; \mathrm{Pd}^{2}-\mathrm{P}^{2}-\mathrm{O}^{3}$ 123.91(9); $\mathrm{Pd}-\mathrm{P}^{2}-\mathrm{O}^{4} 110.02(10) ; \mathrm{Pd}-\mathrm{P}^{1}-\mathrm{C}^{41} 109.87(11) ; \mathrm{Pd}-\mathrm{P}^{2}-\mathrm{C}^{54} 108.57(12) ; \mathrm{C}^{46}-\mathrm{O}^{5}-\mathrm{C}^{56} 112.6(3) ; \mathrm{C}^{45}-\mathrm{C}^{47}-\mathrm{C}^{50} 106.8(3) ;$ $\mathrm{O}^{1}-\mathrm{P}^{1}-\mathrm{C}^{41} 106.07(13) ; \mathrm{O}^{2}-\mathrm{P}^{1}-\mathrm{C}^{41} 102.70(13) ; \mathrm{O}^{3}-\mathrm{P}^{2}-\mathrm{C}^{54} 102.50(14) ; \mathrm{O}^{4}-\mathrm{P}^{2}-\mathrm{C}^{54} 107.67(15)$ 
metallated Pd-diphosphonite species described previously by our group. ${ }^{[16]}$

The structure of complex 2 also bears close resemblance to the molecular structures for the related platinum complex of ligand 1, which will be communicated elsewhere, ${ }^{[23]}$ as well as for cis-[ $\mathrm{PtCl}_{2}$ (Xantphos)]. ${ }^{[24]}$ This indicates that such dispositioning of the metal atom is highly favored in the crystal packing regardless of the metal atom involved. This phenomenon must therefore be based on steric crowding induced by the binaphthyl units. The dihedral angle of the two aromatic rings in the xanthene backbone is found to be $107.8^{\circ}$. The distance between the two phosphorus atoms is 3.4455(12) $\AA$, while the distance between the palladium atom and the oxygen atom in the backbone is $3.284(2) \AA$, which is too long to expect any interaction. ${ }^{[25]}$

When ligand $(R, R)-\mathbf{1}$ was reacted with $\mathrm{Rh}(\mathrm{cod})(\mathrm{acac})$, the ${ }^{31} \mathrm{P}$ NMR spectrum reveals two doublets of doublets, ascribed to the cationic complex $3,[\mathrm{Rh}(\operatorname{cod})(\mathbf{1})] \mathrm{BF}_{4}$. The average signals appear at $\delta=169.7 \mathrm{ppm}$ and at $\delta=$ $161.4 \mathrm{ppm}$, with coupling constants ${ }^{1} J_{\mathrm{Rh}-\mathrm{P}}$ of $218 \mathrm{~Hz}$ and ${ }^{2} J_{\mathrm{P}, \mathrm{P}}$ of $24 \mathrm{~Hz}$. Although no further characterization was performed on this compound, the existence of this $\mathrm{ABX}$ pattern implies that the two phosphorus atoms are chemically inequivalent in the rhodium complex, as in the palladium case. The $\mathrm{Rh}-\mathrm{P}$ coupling constant is similar to values reported by Börner, ${ }^{[13]}$ Puddephatt, ${ }^{[26]}$ and Shum, ${ }^{[27]}$ although the latter report dealt with a $\mathrm{Rh}$ (acac)-diphosphonite derivative, with a ${ }^{1} J_{\mathrm{Rh}-\mathrm{P}}$ of $266 \mathrm{~Hz}$.

\section{Asymmetric Hydroformylation}

In order to evaluate the catalytic properties of enantiomerically pure $(R, R)-\mathbf{1}$, it was applied in the rhodium-catalyzed asymmetric hydroformylation of styrene (Scheme 2). To the best of our knowledge, no reports have appeared on the use of chiral diphosphonite ligands in rhodium-catalyzed asymmetric hydroformylation. As a rhodium precursor, $\mathrm{Rh}(\mathrm{acac})(\mathrm{CO})_{2}$ was used. Before addition of the substrate, the catalytic system was activated for $1 \mathrm{~h}$ with 20 bar syngas at the reaction temperature to generate the catalytic resting state.

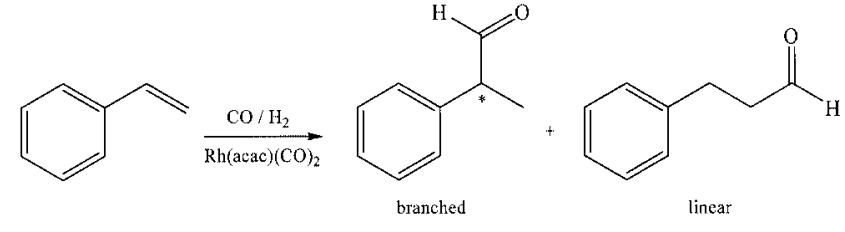

Scheme 2. General reaction scheme for the Rh-catalyzed hydroformylation of styrene

Several hydroformylation experiments were performed at different synthesis gas pressures (10 and 20 bar) and at different temperatures $\left(40-100{ }^{\circ} \mathrm{C}\right)$. The amount of hydrogenation was usually less than $1 \%$ and no other side products were formed. The results obtained are summarized in Table 1 . At $40{ }^{\circ} \mathrm{C}$, a pressure of 20 bar instead of $10 \mathrm{bar}$ led to an increase in the reaction rate of approximately $33 \%$. The enantiomeric excess was found to be lower (entry 2 vs. 1). The selectivity for the branched aldehyde remained constant within experimental error. Turnover frequencies were determined at conversion levels of around $20-40 \%$ from the linear increase of conversion in time. Several samples were taken throughout the reaction without pressure loss.

The effect of pressure on the reaction rate is more significant at temperatures of $60^{\circ} \mathrm{C}$ and higher. In all cases, the initial activity (TOF) is lower at higher pressures. Also, the enantioselectivity is lower at higher pressure. The regioselectivity shows a reverse trend, viz. a positive effect of pressure on the regioselectivity to branched product and a negative influence of the reaction temperature. This is more pronounced at a pressure of $10 \mathrm{bar}$, as the regioselectivity is only $56 \%$ at $100{ }^{\circ} \mathrm{C}$ and increases to $81 \%$ at 20 bar. In all cases, the enantiomeric excess (ee) is poor, with a maximum of $33 \%$ at $100{ }^{\circ} \mathrm{C}$.

No attempts were made to modify the ligand system in order to obtain higher enantioselectivity. Goertz et al. already showed that for the asymmetric hydrocyanation, the introduction of bulky substituents in the 3,3'-positions of the binaphthyl units can lead to higher ee's. ${ }^{[14]}$ Buisman et al. observed a similar effect in the asymmetric hydrofor-

Table 1. Rh-catalyzed asymmetric hydroformylation of styrene applying $(R, R)$-XantBino (1)

\begin{tabular}{|c|c|c|c|c|c|c|c|}
\hline Entry ${ }^{[a]}$ & $T\left[{ }^{\circ} \mathrm{C}\right]$ & $p$ [bar] & Time $[\mathrm{h}]$ & Conversion $[\%]^{[\mathrm{b}]}$ & Sel. branched $[\%]^{[\mathrm{b}]}$ & $e e[\%]^{[\mathrm{c}]}$ & TOF $\left[h^{-1}\right]^{[\mathrm{d}]}$ \\
\hline $1^{[\mathrm{e}]}$ & 40 & 10 & 48 & 63 & 91 & $17(R)$ & 12 \\
\hline $2^{[\mathrm{e}]}$ & 40 & 20 & 72 & 90 & 92 & $13(R)$ & 17 \\
\hline 3 & 60 & 10 & 5 & 54 & 85 & $22(R)$ & 260 \\
\hline 4 & 60 & 20 & 8 & 93 & 87 & $16(R)$ & 140 \\
\hline 5 & 80 & 10 & 3 & 99 & 80 & $27(R)$ & 880 \\
\hline 6 & 80 & 20 & 3 & 100 & 85 & $20(R)$ & 720 \\
\hline 7 & 100 & 10 & 2 & 94 & 56 & $33(R)$ & n.d. \\
\hline 8 & 100 & 20 & 2 & 96 & 81 & $24(R)$ & n.d. \\
\hline
\end{tabular}

[a] Reaction conditions: $1.55 \mathrm{~mL}$ styrene $(13.5 \mathrm{mmol}) ; 3.45 \mathrm{~mL}$ toluene; $\left[\mathrm{Rh}(\mathrm{acac})(\mathrm{CO})_{2}\right]=0.9 \mathrm{~mm}, \mathrm{~L}: \mathrm{Rh}=1.2: 1 ;$ styrene: $\mathrm{Rh}=1000: 1$. ${ }^{[b]}$ Determined by GC analysis. ${ }^{[c]}$ Enantiomeric excess, determined by chiral GC analysis. [d] Turnover frequency determined at $20-40 \%$ conversion; defined as (mol substrate converted) $\cdot(\text { mol rhodium })^{-1} \cdot h^{-1}$. [e] Preformation time 15 hours. 
mylation of styrene but with diphosphites derived from less rigid backbones. ${ }^{[4]}$ Furthermore, steric crowding around these positions led to a significant decrease in enantioselectivity.

As with thermodynamic control of the stereoselection, the ee decreases when the temperature is increased, and experiments are usually conducted at low temperature. ${ }^{[28-30]}$ There are nonetheless some studies on the rhodium-catalyzed hydroformylation of styrene in which the enantioselectivity increased with increasing temperature. ${ }^{[31-34]}$ Hanson et al. studied the Pt/Sn-catalyzed asymmetric hydroformylation with diamino-substituted versions of the known ligands CHIRAPHOS and BDPP. A linear decrease in the ee with temperature was observed using the CHIRAPHOS derivative, while with the BDPP ligand the sign of enantioselection changed with temperature. The $(S)$-enantiomer was formed in excess at low temperature, while the $(R)$-enantiomer was the major product at $60{ }^{\circ} \mathrm{C}$ and above. Furthermore, the enantioselectivity of the $(R)$-enantiomer increased with reaction temperature, contradictory to the "normal' behavior seen with CHIRAPHOS. This phenomenon, already discussed by Scharf in a review on dramatic temperature effects on selectivities in catalysis, ${ }^{[35]}$ was explained by the existence of competing pathways of diastereomeric intermediates of a single chelate conformation of the catalyst system, hence indicating kinetic control.

For the catalytic system with ligand $\mathbf{1}$ we also observed a positive dependency of the enantiomeric excess on the reaction temperature, as illustrated in Figure 5. The highest ee of $33 \%$ is found at $100{ }^{\circ} \mathrm{C}$ and 10 bar. The ee is lower at higher pressure (for example, entries 3 and 4 vs. 5 and 6 in Table 1). A discussion on the proposed mechanism for this particular system is discussed hereafter (vide infra).

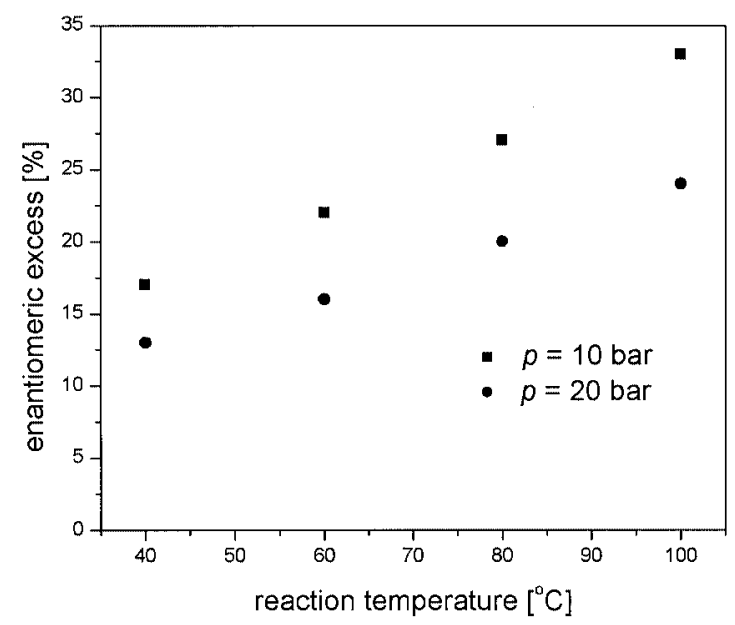

Figure 5. Plot of the positive relationship between the ee and the reaction temperature, at two pressures

It is known that the results obtained in the rhodium-catalyzed asymmetric hydroformylation of vinyl acetate can be drastically different when applying the same catalytic system. ${ }^{[36]}$ We were therefore interested to see how our $\mathrm{Rh} /(\mathbf{1})$

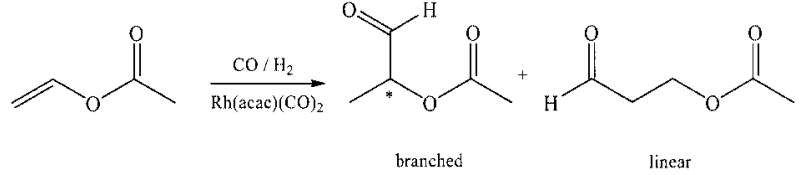

Scheme 3. General reaction scheme for the Rh-catalyzed hydroformylation of vinyl acetate

system would perform in this specific reaction (Scheme 3). The substrate vinyl acetate differs from styrene in two important aspects, viz. a) vinyl acetate cannot form $\eta^{3}$ complexes and b) the carbonyl oxygen can participate in bonding to the metal.

In all catalytic runs the catalyst was preformed for 1 hour at $60{ }^{\circ} \mathrm{C}$ and 10 bar. Reaction at $60{ }^{\circ} \mathrm{C}$ and 20 bar of $\mathrm{H}_{2}$ led to an enantiomeric excess of $51 \%$, which is significantly higher than for styrene. The regioselectivity was extremely high with an b/l ratio exceeding 90 . The reaction of vinyl acetate showed the normal temperature dependence; the $e e$ dropped to $33 \%$ at a reaction temperature of $80{ }^{\circ} \mathrm{C}$. This supports the hypothesis that the $\eta^{3}$-benzyl intermediate might induce kinetic control of the ee with styrene as a substrate, leading to an unusual temperature effect. Since this intermediate species is absent in the case of vinyl acetate, no such dependence was found for this substrate.

\section{Asymmetric Hydrogenation}

As a third test reaction, diphosphonite $\mathbf{1}$ was applied in the Rh-catalyzed asymmetric hydrogenation of methyl $(Z)$ 2-acetamidocinnamate (I) (Scheme 4). ${ }^{[37]}$

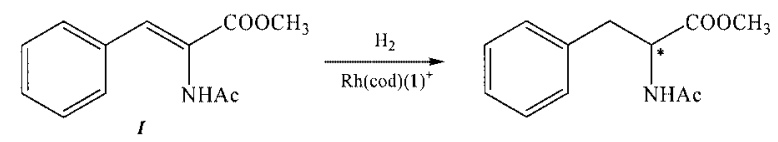

Scheme 4. General reaction scheme for the Rh-catalyzed hydrogenation of methyl $(Z)$-2-acetamidocinnamate

The catalysis was carried out at ambient temperature, with a substrate to rhodium ratio $(\mathrm{S} / \mathrm{Rh})$ of $100: 1$. Before addition of the substrate, a concentrated solution of $[\mathrm{Rh}(\operatorname{cod})(\mathbf{1})] \mathrm{BF}_{4}$, complex 3 , in methanol was stirred for 3 hours under 1.2 bar of $\mathrm{H}_{2}$ in order to preform the catalyst. During catalysis a static $\mathrm{H}_{2}$ pressure (1.2 or 5 bar) was applied. The reaction rate was constant up to $80 \%$ conversion for the reaction that applied 1.2 bar of $\mathrm{H}_{2}$, indicating that the catalyst system remains stable and active. Also the ee remained constant at $54 \%$ over the full conversion range. Substrate depletion leads to the expected drop in reaction rate at even higher conversion. Under these nonoptimized conditions, the rates were low (about $40 \mathrm{~h}^{-1}$ ) relative to rates reported by Reetz ${ }^{[8 a]}$ and Claver ${ }^{[8 b]}$ for the hydrogenation of different substrates that applied diphosphonites. For the paracyclophane-based diphosphonite system employed by Zanotti-Gerosa, ${ }^{[8 c]}$ TON's of up to $2000 \mathrm{~h}^{-1}$ were reported. 
The enantioselectivity of $54 \%$ with the present $[\mathrm{Rh}(\operatorname{cod})(\mathbf{1})] \mathrm{BF}_{4}$ system 3 is promising, but still moderate compared with the diphosphonite systems mentioned before (vide supra). The $(S)$-enantiomer is formed in excess with the catalyst containing $(R, R)-(\mathbf{1})$. Similar catalytic results were obtained when applying a pressure of 5 bar $\mathrm{H}_{2}$. After 2 hours, the conversion reached $94 \%$, with an ee of $47 \%$. The higher activity is expected since the concentration of hydrogen is evidently increased.

\section{Temperature Dependence in Asymmetric Hydroformylation of Styrene}

In the case of transition metal catalyzed functionalization of vinyl arenes, participation of $\eta^{3}$-benzyl intermediates (Scheme 5) have been discussed..$^{[38-41]}$ Depending on the ligand influence and on the temperature, pre-equilibria can exist that involve coordination of the substrate, $\sigma$-alkyl and $\eta^{3}$-benzyl intermediates. Obviously chirality is already induced during substrate binding but the direction could be influenced by a reversible insertion step. With (our) $\pi$-acceptor ligands the $\eta^{3}$-benzyl species could be favored, especially at low temperature giving rise to thermodynamic control over the enantioselection. At higher temperature, the $\sigma$-alkyl species could become more important, possibly resulting in a kinetically controlled process. This is in line with the pressure dependence of the $e e$ and of the b/l ratio observed (vide supra) as higher CO pressure will slow down pre-equilibria and enhance product formation from intermediates once they are formed. Definitely, this effect is very interesting, and shedding more light on the underlying processes will give new insight into the stereoselection mechanism of the asymmetric hydroformylation. Unfortunately, the available data do not allow any conclusions yet. Detailed studies on this phenomenon are presently underway.

\section{Conclusions}

The synthesis of diphosphonite ligand $\mathbf{1}$ (XantBino) has been improved. The coordination chemistry of this ligand was explored for palladium and rhodium. The molecular structure for $c i s-\left[\mathrm{PdCl}_{2}(\mathbf{1})\right]$, complex $\mathbf{2}$, has been described, revealing an out-of-plane positioning of the metal atom at a dihedral angle of $115^{\circ}$. The bite angle of $100^{\circ}$ of the diphosphonite ligand is unusually small for a xanthene-derived phosphorus ligand. The first application of a chiral diphosphonite in the rhodium-catalyzed asymmetric hydroformylation of styrene is reported, leading to high activities with turnover frequencies of up to $1420 \mathrm{~h}^{-1}$. The maximum enantioselectivity obtained was low; however an interesting increase was observed at higher temperature. In the asymmetric hydrogenation of methyl (Z)-2-acetamidocinnamate, low activities were found, yet the enantioselectivity was promising, with an enantiomeric excess of $54 \%$, which is encouraging, given the nonoptimized structure and conditions.

\section{Experimental Section}

General: Chemicals were purchased from Aldrich, Acros and Merck, and used as received. Synthesis gas $\left(\mathrm{CO} / \mathrm{H}_{2}, 1: 1\right)$ was purchased from Carburos Metalicos. All preparations were carried out under argon using standard Schlenk techniques. Solvents were distilled from sodium/benzophenone (THF, ether, toluene, hexane and ethanol) or calcium hydride $\left(\mathrm{CH}_{2} \mathrm{Cl}_{2}\right.$ and $\left.\mathrm{CDCl}_{3}\right)$ prior to use. All glassware was dried by heating under vacuum. The NMR spectra were recorded on a Varian Mercury 400 spectrometer $\left({ }^{1} \mathrm{H}\right.$, $\left.{ }^{13} \mathrm{C}\left\{{ }^{1} \mathrm{H}\right\},{ }^{31} \mathrm{P}\left\{{ }^{1} \mathrm{H}\right\}\right)$. Chemical shifts are given in ppm referenced to solvent $\left({ }^{1} \mathrm{H},{ }^{13} \mathrm{C}\left\{{ }^{1} \mathrm{H}\right\}\right)$ or an $85 \%$ aqueous solution of $\mathrm{H}_{3} \mathrm{PO}_{4}$ $\left({ }^{31} \mathrm{P}\left\{{ }^{1} \mathrm{H}\right\}\right)$. GC spectra were recorded on a Hewlett-Packard 5890A Chromatograph equipped with a Ultra-2 column (styrene) or a Shimadzu 17A with a PONA column (vinyl acetate and hydro-

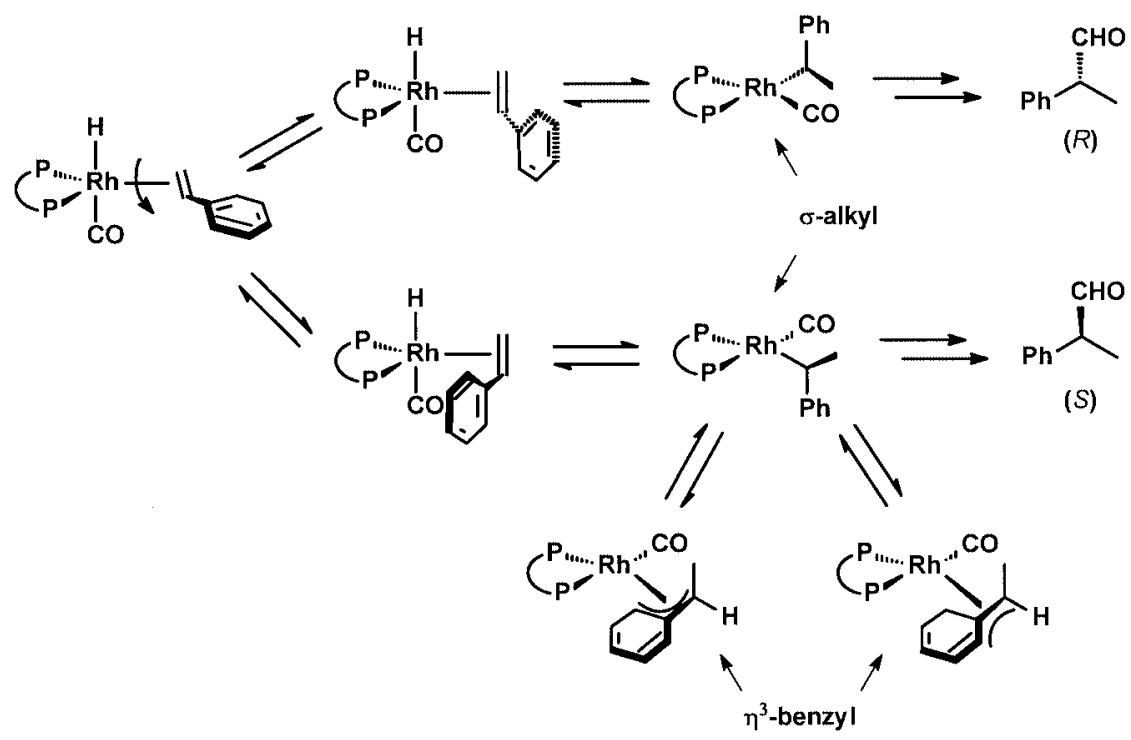

Scheme 5. Proposed stereoselection mechanism in the rhodium-catalyzed asymmetric hydroformylation of styrene (and other vinyl arenes) 
genation). Enantiomeric excesses were determined on a Hewlett-Packard 5890A with a Cyclodex $\beta$-I/P column (styrene) a GC Vega 6000 equipped with a Cyclodex $\beta-\mathrm{I} / \mathrm{P}$ column (vinyl acetate) or a Shimadzu 2010 equipped with a Chirasil-L-Val column (hydrogenation). $\mathrm{PdCl}_{2}(\mathrm{cod}),{ }^{[42]}[\mathrm{Rh}(\mathrm{cod}) \mathrm{Cl}]_{2},{ }^{[43]}$ and $[\mathrm{Rh}(\mathrm{cod})-$ (acac) $]^{[44]}$ were prepared according to literature procedures.

4,5-Bis[bis(diethylamino)phosphonito]-9,9-dimethylxanthene: ${ }^{[14]}$ 9,9-dimethylxanthene $(2.85 \mathrm{~g}, 13.56 \mathrm{mmol})$ and $N, N, N^{\prime}, N^{\prime}$-tetramethylethylenediamine (TMEDA) $(3.32 \mathrm{~g}, 28.48 \mathrm{mmol})$ were dissolved in diethyl ether $(50 \mathrm{~mL})$. The solution was cooled to -40 ${ }^{\circ}$ C. $n$-Butyllithium $(11.4 \mathrm{~mL}, 2.5 \mathrm{M}$ in hexane) was added to the mixture dropwise. The solution was allowed to warm up to room temperature and stirred overnight. $\mathrm{ClP}\left(\mathrm{NEt}_{2}\right)_{2}(6.0 \mathrm{~g}, 18.99 \mathrm{mmol})$ was dissolved in diethyl ether $(40 \mathrm{~mL})$ and added to the reaction mixture at $-80{ }^{\circ} \mathrm{C}$. The solution was allowed to warm up to room temperature and stirred overnight. The solvent was removed by evaporation, and the resulting solid was dissolved in pentane $(40 \mathrm{~mL})$ and filtered to remove solids. Excess TMEDA was removed by azeotropic evaporation with toluene $(3 \times 20 \mathrm{~mL})$. Pentane $(10 \mathrm{~mL})$ was added to the solid, and the mixture was stored overnight at $-25^{\circ} \mathrm{C}$. The crystals that had formed were separated from the solution by filtration. The crystals were dried in vacuo, yielding a pure dark yellow solid. Yield (4.64 g, 61.3\%). ${ }^{1} \mathrm{H}$ NMR $\left(\mathrm{CDCl}_{3}\right): \delta=7.38(\mathrm{~m}, 4 \mathrm{H}), 7.02(\mathrm{~d}, 2 \mathrm{H}), 3.05\left(\mathrm{~m}, 16 \mathrm{H}, \mathrm{NCH}_{2}\right)$, $1.60\left(6 \mathrm{H}, \mathrm{CCH}_{3}\right), 1.00\left(\mathrm{~m}, 24 \mathrm{H}, \mathrm{NCH}_{3}\right) \mathrm{ppm} .{ }^{31} \mathrm{P}\left\{{ }^{1} \mathrm{H}\right\} \mathrm{NMR}$ $\left(\mathrm{CDCl}_{3}\right): \delta=91.5$ (s) ppm.

$(R, R)-4,5-B i s(\operatorname{dinaphtho}[d, f][1,3,2]$ dioxaphosphepin-4-yl)-9,9-dimethylxanthene (1): This is a modification of a literature procedure. $^{[14]}$ 4,5-Bis[bis(diethylamino)phosphonito]-9,9-dimethylxanthene $(2.00 \mathrm{~g}, 3.58 \mathrm{mmol})$ and $(R)-(+)-2,2^{\prime}$-dihydroxy-1,1'-binaphthyl $(2.05 \mathrm{~g}, 7.16 \mathrm{mmol})$ were dissolved in toluene $(50 \mathrm{~mL})$. A catalytic quantity of tetrazole (about $10 \mathrm{mg}, 0.14 \mathrm{mmol}$ ) was added as a protonation agent. The solution was heated to $90^{\circ} \mathrm{C}$ for 16 hours. Diethylamine formed during the reaction was removed twice under vacuum. After reaction, the solvent was removed in vacuo, and the remaining crude product was dissolved in $\mathrm{CH}_{2} \mathrm{Cl}_{2}(5 \mathrm{~mL})$ and layered with acetonitrile $(20 \mathrm{~mL})$. The precipitated product was isolated by filtration and washed with acetonitrile $(10 \mathrm{~mL})$. After drying, a yellow powder was obtained as a pure product $(0.70 \mathrm{~g}, 31 \%)$. The other enantiomer can be obtained by the same procedure. ${ }^{1} \mathrm{H}$ NMR $\left(\mathrm{CDCl}_{3}\right): \delta=7.94\left(\mathrm{~d},{ }^{1} J=8.8 \mathrm{~Hz}, 2 \mathrm{H}\right.$, binolH), $7.90(\mathrm{~d}$, ${ }^{1} J=8.0 \mathrm{~Hz}, 2 \mathrm{H}$, binolH), $7.84\left(\mathrm{~d},{ }^{1} J=8.0 \mathrm{~Hz}, 2 \mathrm{H}\right.$, binolH), 7.63 $\left(\mathrm{d},{ }^{1} J=8.8 \mathrm{~Hz}, 2 \mathrm{H}\right.$, binolH), $7.58\left(\mathrm{~d},{ }^{1} J=8.8 \mathrm{~Hz}, 2 \mathrm{H}\right.$, binolH), $7.55\left(\mathrm{dd},{ }^{1} \mathrm{~J}=8.0,{ }^{2} \mathrm{~J}=0.8 \mathrm{~Hz}, 2 \mathrm{H}\right.$, binolH), $7.42\left(\mathrm{t},{ }^{1} \mathrm{~J}=8.8 \mathrm{~Hz}\right.$, $6 \mathrm{H}, \mathrm{ArH}), 7.32\left(\mathrm{~d},{ }^{1} \mathrm{~J}=8.4 \mathrm{~Hz}, 2 \mathrm{H}\right.$, binolH), 7.28 (dquin, $4 \mathrm{H}$, ${ }^{1} J=8.0,{ }^{2} J=1.2 \mathrm{~Hz}$, binolH) $7.18\left(\mathrm{~d},{ }^{1} J=8.8 \mathrm{~Hz}, 2 \mathrm{H}\right.$, binolH), $6.92\left(\mathrm{~d},{ }^{1} J=8.8 \mathrm{~Hz}, 2 \mathrm{H}\right.$, binolH $), 6.90\left(\mathrm{~d},{ }^{1} J=7.2 \mathrm{~Hz}, 4 \mathrm{H}\right.$, binolH), $1.79\left[\mathrm{~s}, 6 \mathrm{H}, \mathrm{C}\left(\mathrm{CH}_{3}\right)_{2}\right] \mathrm{ppm} .{ }^{13} \mathrm{C} \mathrm{NMR}\left(\mathrm{CDCl}_{3}\right): \delta=$ $152.6,149.9,149.1,133.0,132.5,131.5,130.9,130.4,129.9,129.0$ $\left(\mathrm{d}, J_{\mathrm{P}, \mathrm{C}}=16.8 \mathrm{~Hz}\right), 128.5,128.2\left(\mathrm{~d}, J_{\mathrm{P}, \mathrm{C}}=6.8 \mathrm{~Hz}\right), 126.9\left(\mathrm{~d}, J_{\mathrm{P}, \mathrm{C}}=\right.$ $3.8 \mathrm{~Hz}), 125.8\left(\mathrm{~d}, J_{\mathrm{P}, \mathrm{C}}=19.0 \mathrm{~Hz}\right), 124.6\left(\mathrm{~d}, J_{\mathrm{P}, \mathrm{C}}=20.6 \mathrm{~Hz}\right), 123.3$, $121.9\left(\mathrm{~d}, J_{\mathrm{P}, \mathrm{C}}=5.3 \mathrm{~Hz}\right), 34.1\left[\mathrm{C}\left(\mathrm{CH}_{3}\right)_{2}\right], 31.9\left[\mathrm{C}\left(\mathrm{CH}_{3}\right)_{2}\right] \mathrm{ppm}$. ${ }^{31} \mathrm{P}\{! \mathrm{H}\} \mathrm{NMR}\left(\mathrm{CDCl}_{3}\right): \delta=178.0$ (s) ppm. $\mathrm{C}_{55} \mathrm{H}_{36} \mathrm{O}_{5} \mathrm{P}_{2}(838.82 \mathrm{~g}$ $\mathrm{mol}^{-1}$ ): calcd. C 78.75, H 4.33; found C 78.52, $\mathrm{H} \mathrm{4.18 \% .}$

cis-[PdCl $\mathbf{2}((\boldsymbol{S}, S)-1)]$ (complex 2): $\mathrm{PdCl}_{2}(\operatorname{cod})(13.2 \mathrm{mg}, 46.2 \mu \mathrm{mol})$ and $(S, S)-1(38.7 \mathrm{mg}, 46.2 \mu \mathrm{mol})$ were dissolved in $\mathrm{CH}_{2} \mathrm{Cl}_{2}(5 \mathrm{~mL})$ and stirred for 1 hour at room temperature. The solvent was removed in vacuo to leave a light-yellow solid. Yellow block-shaped crystals of complex $\mathbf{2}$ were grown by slow diffusion of acetonitrile into a dichloromethane solution. ${ }^{1} \mathrm{H}$ NMR $\left(\mathrm{CDCl}_{3}\right): \delta=8.37$ (d, $\left.{ }^{1} J=8.8 \mathrm{~Hz}, 1 \mathrm{H}\right), 8.20\left(\mathrm{~d},{ }^{1} J=8.8 \mathrm{~Hz}, 1 \mathrm{H}\right), 8.16\left(\mathrm{~d},{ }^{1} J=8.8 \mathrm{~Hz}\right.$, $1 \mathrm{H}), 8.08\left(\mathrm{~d},{ }^{1} J=8.8 \mathrm{~Hz}, 1 \mathrm{H}\right), 8.03\left(\mathrm{t},{ }^{1} \mathrm{~J}=8.8 \mathrm{~Hz}, 1 \mathrm{H}\right), 8.00$ $\left(\mathrm{d},{ }^{1} J=8.8 \mathrm{~Hz}, 1 \mathrm{H}\right), 7.95\left(\mathrm{dd},{ }^{1} J=8.0,{ }^{2} J=4.8 \mathrm{~Hz}, 2 \mathrm{H}\right), 7.89$ $\left(\mathrm{d},{ }^{1} J=8.8 \mathrm{~Hz}, 1 \mathrm{H}\right), 7.81(\mathrm{~m}, 2 \mathrm{H}), 7.70(\mathrm{~m}, 3 \mathrm{H}), 7.65\left(\mathrm{dt},{ }^{1} J=\right.$ $\left.8.4,{ }^{2} J=1.2 \mathrm{~Hz}, 1 \mathrm{H}\right), 7.58\left(\mathrm{t},{ }^{1} J=8.8 \mathrm{~Hz}, 1 \mathrm{H}\right), 7.56\left(\mathrm{t},{ }^{1} J=\right.$ $8.0 \mathrm{~Hz}, 2 \mathrm{H}), 7.51\left(\mathrm{dd},{ }^{1} J=7.2,{ }^{2} J=1.2 \mathrm{~Hz}, 1 \mathrm{H}\right), 7.46(\mathrm{~m}, 1 \mathrm{H})$, $7.46\left(\mathrm{t},{ }^{1} J=8.0 \mathrm{~Hz}, 1 \mathrm{H}\right), 7.34(\mathrm{~m}, 2 \mathrm{H}), 7.23(\mathrm{~m}, 2 \mathrm{H}), 7.21(\mathrm{t}$, $\left.{ }^{1} J=6.8 \mathrm{~Hz}, 1 \mathrm{H}\right), 7.13(\mathrm{~m}, 1 \mathrm{H}), 7.09\left(\mathrm{dd},{ }^{1} J=6.4,{ }^{2} J=2.0 \mathrm{~Hz}\right.$, $1 \mathrm{H}), 6.90\left(\mathrm{~d},{ }^{1} J=8.8 \mathrm{~Hz}, 1 \mathrm{H}\right), 6.09\left(\mathrm{~d},{ }^{1} J=9.6 \mathrm{~Hz}, 1 \mathrm{H}\right), 1.96$ (s, $\left.3 \mathrm{H}, \mathrm{CCH}_{3}\right), 1.67\left(\mathrm{~s}, 3 \mathrm{H}, \mathrm{CCH}_{3}\right) \mathrm{ppm} .{ }^{31} \mathrm{P}\left\{{ }^{1} \mathrm{H}\right\} \mathrm{NMR}\left(\mathrm{CDCl}_{3}\right)$ : $\delta=143.1\left(\mathrm{~d}, J_{\mathrm{P}, \mathrm{P}}=46.5 \mathrm{~Hz}\right), 137.4\left(J_{\mathrm{P}, \mathrm{P}}=46.5 \mathrm{~Hz}\right) \mathrm{ppm}$. $\mathrm{C}_{55} \mathrm{H}_{36} \mathrm{Cl}_{2} \mathrm{O}_{5} \mathrm{P}_{2} \mathrm{Pd}\left(1016.14 \mathrm{~g} \mathrm{~mol}^{-1}\right)$ : calcd. C 65.01, H 3.57; found C $65.34, \mathrm{H} 3.63 \%$.

$[\mathbf{R h}(\operatorname{cod})((\boldsymbol{R}, \boldsymbol{R})-\mathbf{1})] \mathrm{BF}_{4}($ complex 3): This is a modification of a generic literature procedure. ${ }^{[45]}[\mathrm{Rh}(\mathrm{cod})(\mathrm{acac})](0.047 \mathrm{~g}, 0.15 \mathrm{mmol})$ was dissolved in THF ( $2 \mathrm{~mL}) . \mathrm{HBF}_{4}(54 \%$ solution in diethyl ether) $(0.053 \mathrm{~g}, 0.60 \mathrm{mmol})$ was added. During addition, the solution colored darker. $(R, R)-1(0.126 \mathrm{~g}, 0.15 \mathrm{mmol})$ was dissolved in THF $(2 \mathrm{~mL})$ and added to the solution, yielding an orange suspension. Diethyl ether (approximately $20 \mathrm{~mL}$ ) was added, and the mixture was stirred vigorously for 5 minutes. The yellow precipitate formed was isolated and washed with diethyl ether $(10 \mathrm{~mL})$. Volatiles were removed in vacuo to leave a yellow/orange solid. Yield 68\% (0.14 g, $0.10 \mathrm{mmol}) .{ }^{31} \mathrm{P}\left\{{ }^{1} \mathrm{H}\right\}$ NMR $\left(\mathrm{CDCl}_{3}\right): \delta=169.3\left(\mathrm{dd}, J_{\mathrm{Rh}-\mathrm{P}}=219\right.$, $\left.J_{\mathrm{P}-\mathrm{P}}=24 \mathrm{~Hz}\right), 161.1\left(\mathrm{dd}, J_{\mathrm{Rh}-\mathrm{P}}=216, J_{\mathrm{P}-\mathrm{P}}=24 \mathrm{~Hz}\right.$.) $) \mathrm{ppm}$.

Hydroformylation of Styrene: Reactions were performed using a stainless steel autoclave $(75 \mathrm{~mL})$ equipped with an inner glass beaker. Styrene was filtered through neutral alumina before use. Generally, $\mathrm{Rh}(\mathrm{acac})(\mathrm{CO})_{2}(3.5 \mathrm{mg}, 13.5 \mu \mathrm{mol})$ and $\mathbf{1}$ (1.2 equiv.) were both dissolved in toluene $(5 \mathrm{~mL})$, and the combined solution was brought into the preheated autoclave, which was then pressurized to 20 bar of synthesis gas. After the appropriate preformation time, the autoclave was depressurized, and the substrate solution, containing styrene $(1.55 \mathrm{~mL}, 13.5 \mathrm{mmol})$ in toluene $(3.45 \mathrm{~mL})$ was added, and 20 bar of synthesis gas was applied. During catalysis, samples were withdrawn without pressure loss for GC analysis. After reaction, the autoclave was cooled and depressurized, and the reaction mixture taken out. Oxidation of the aldehydes to the carboxylic acids was done directly afterwards, to prevent racemization and to allow for analysis by chiral GC.

Hydroformylation of Vinyl Acetate: Reactions were performed using a stainless steel autoclave $(75 \mathrm{~mL})$ equipped with an inner glass beaker. Generally, $\mathrm{Rh}(\mathrm{acac})(\mathrm{CO})_{2}(3.0 \mathrm{mg}, 11.6 \mu \mathrm{mol})$ and 1 ( 2 equiv.) were both dissolved in benzene $(10 \mathrm{~mL})$, and the combined solution was charged into the autoclave, which was then pressurized to 20 bar of synthesis gas and heated to reaction temperature. After preformation, vinyl acetate $(1.5 \mathrm{~mL}, 16.3 \mathrm{mmol})$ in benzene $(5 \mathrm{~mL})$ was added. After reaction, the reaction mixture was quantitatively withdrawn, and a weighed amount of ethyl propionate $(0.5 \mathrm{~mL}, 4.4 \mathrm{mmol})$ was added. After a quantitative distillation, an aliquot was withdrawn for GC analysis (both for conversion and enantiomeric excess).

Hydrogenation of Methyl (Z)-2-Acetamidocinnamate (I): Reactions were carried out in a stainless steel autoclave $(75 \mathrm{~mL}) .3(11.4 \mathrm{mg}$, $0.01 \mathrm{mmol})$ was dissolved in methanol $(1 \mathrm{~mL})$, and the solution was activated under 1 bar of $\mathrm{H}_{2}$ for 2 hours. Methyl (Z)-2-acetamidocinnamate $(0.22 \mathrm{~g}, 1.00 \mathrm{mmol})$ was dissolved in methanol $(9 \mathrm{~mL})$, and the substrate solution was charged into the catalyst solution, and the appropriate $\mathrm{H}_{2}$ pressure was applied. During reaction, samples were withdrawn for GC analysis.

Crystal Structure Determination of 2: Intensity data were collected using graphite-monochromated Mo- $K_{\alpha}$ radiation, on a Nonius KappaCCD diffractometer. A correction for absorption was con- 
sidered unnecessary. The structure was solved by automated direct methods using SHELXS-97, ${ }^{[46]}$ and refined on $F^{2}$ using SHELXL97. ${ }^{[47]}$ The absolute configuration of $\mathbf{2}$ was established by anomalous dispersion effects to be $(S, S)-\left[\mathrm{PdCl}_{2}(\mathbf{1})\right]$, Flack parameter 0.013 (19). The crystal structure contains voids (1406.0 $\AA^{3} /$ unit cell) filled with disordered solvent molecules (dichloromethane/acetonitrile). Their contribution to the structure factors was ascertained using PLATON/SQUEEZE (499 e/unit cell). All non-hydrogen atoms were refined with anisotropic displacement parameters. All hydrogen atoms were constrained to idealized geometries and allowed to ride on their carrier atoms with an isotropic displacement parameter related to the equivalent displacement parameter of their carrier atoms. Structure validation and molecular graphics preparation were performed with the PLATON package. ${ }^{[48]}$ CCDC-231720 contains the supplementary crystallographic data for this paper. These data can be obtained free of charge at www.ccdc.cam.ac.uk/conts/retrieving.html (or from the CCDC, 12 Union Road, Cambridge CB2 1EZ, UK; Fax: +44-1223-336033; E-mail: deposit@ccdc.cam.ac.uk).

Table 2. Selected crystallographic data for complex 2, cis$\left[\mathrm{PdCl}_{2}(\mathbf{1})\right] ; R_{\text {int }}=\Sigma\left[\mid F_{\mathrm{o}}{ }^{2}-F_{\mathrm{o}}{ }^{2}(\right.$ mean $\left.) \mid\right] / \Sigma\left[F_{\mathrm{o}}{ }^{2}\right] ; w R\left(F^{2}\right)=\left\{\Sigma\left[w\left(F_{\mathrm{o}}{ }^{2}\right.\right.\right.$ $\left.\left.\left.-F_{\mathrm{c}}\right)^{2}\right] / \Sigma\left[w\left(F_{\mathrm{o}}{ }^{2}\right)^{2}\right]\right\}^{1 / 2} ; R(F)=\Sigma\left(\left\|F_{\mathrm{o}}|-| F_{\mathrm{c}}\right\|\right) / \Sigma\left|F_{\mathrm{o}}\right|$

2

\begin{tabular}{ll}
\hline Formula & $\mathrm{C}_{55} \mathrm{H}_{36} \mathrm{Cl}_{2} \mathrm{O}_{5} \mathrm{P}_{2} \mathrm{Pd}+$ solvent \\
$M\left(\mathrm{~g} \mathrm{~mol}^{-1}\right)$ & $1016.08^{[\mathrm{a}]}$ \\
Crystal size $(\mathrm{mm})$ & $0.06 \times 0.12 \times 0.30$ \\
Crystal system & orthorhombic \\
Space group & $P 2_{1} 2_{1} 2_{1}($ no. 19$)$ \\
$a(\AA)$ & $11.3183(1)$ \\
$b(\AA)$ & $17.4368(1)$ \\
$c(\AA)$ & $27.4181(3)$ \\
$V\left(\AA^{3}\right)$ & $5411.10(8)$ \\
$Z$ & 4 \\
$d_{\text {calcd. }}\left(\mathrm{g} \mathrm{cm}^{-3}\right)$ & $1.247^{[\mathrm{a}]}$ \\
$\mu\left(\mathrm{Mo}-K_{\alpha}\right)\left(\mathrm{mm}^{-1}\right)$ & $0.544^{[\mathrm{a}]}$ \\
$T(\mathrm{~K})$ & 150 \\
Total reflections & 59674 \\
Unique reflections $\left(R_{\text {int }}\right)$ & $12279(0.064)$ \\
$R_{\mathrm{F}}$ & 0.0411 \\
$w R_{2}\left(F^{2}\right)$ (all data) & 0.0975 \\
$F(000)$ & $2064^{[\mathrm{a}]}$ \\
\hline
\end{tabular}

[a] Without disordered solvent.

\section{Acknowledgments}

This research was supported by The National Research School Combination on Catalysis (NRSC-C), Avantium Technologies (E. J. Z.) and in part by the Netherland's Organisation for Scientific Research (CW-NWO) (A. M. M. and A. L. S.). OMG is thanked for a generous gift of precious metals. The Erasmus Program of the European Union is acknowledged for a travel grant (J. P.). Scientific discussions with Dr. Rafael Sablong are highly valued.

[1] [1a] B. Breit, Acc. Chem. Res. 2003, 36, 264-275. [1b] B. Breit, W. Seiche, Synthesis 2001, 1-36; C. Claver, P. W. N. M. van Leeuwen, in Rhodium Catalyzed Hydroformylation (P. W. N. M. van Leeuwen, C. Claver, Eds.), Kluwer, Amsterdam, 2000, 107. [1d] F. Agbossou, J.-F. Carpentier, A. Mortreux, Chem. Rev. 1995, 2485-2506. ${ }^{[1 \mathrm{e}]}$ S. Gladiali, J. C. Bayon, C. Claver, Tetrahedron: Asymmetry 1995, 6, 1453-1474.

${ }^{[2]}{ }^{[2 a]}$ A. Aghmiz, A. Orejón, M. Diéguez, M. D. Miquel-Serrano,
C. Claver, A. M. Masdeu-Bultó, D. Sinou, G. Laurenczy, J. Mol. Cat. A.: Chem. 2003, 195, 113-124. ${ }^{[2 \mathrm{~b}]}$ C. Hegedus, J. Madarasz, H. Gulyas, A. Szollosy, J. Bakos, Tetrahedron: Asymmetry 2001, 12, 2867-2873. ${ }^{[2 \mathrm{c}]}$ C. Bianchini, P. Barbaro, G. Scapacci, J. Organomet. Chem. 2001, 621, 26-33. ${ }^{[2 \mathrm{~d}]} \mathrm{U}$. Nettekoven, P. C. J. Kamer, M. Widhalm, P. W. N. M. van Leeuwen, Organometallics 2000, 19, 4596-4607. ${ }^{[2 \mathrm{e}]} \mathrm{S}$. Lu, X. Li, A. Wang, Catal. Today 2000, 63, 531-536.

[3] [3a] F. Shibahara, K. Nozaki, T. Hiyama, J. Am. Chem. Soc. 2003, $125,8555-8560 .{ }^{[3 b]}$ K. Nozaki, T. Matsuo, F. Shibahara, T. Hiyama, Organometallics 2003, 22, 594-600. ${ }^{[3 \mathrm{c}]}$ O. Pamies, G. Net, A. Ruiz, C. Claver, Tetrahedron: Asymmetry 2002, 12, 3441-3445. ${ }^{[3 \mathrm{~d}]}$ V. Beghetto, A. Scrivanti, U. Matteoli, Catal. Commun. 2001, 2, 139-143. [3e] N. Sakai, S. Mano, K. Nozaki, H. Takaya, J. Am. Chem. Soc. 1993, 115, 7033-7034.

[4] [4a] M. Dieguez, O. Pamies, A. Ruiz, C. Claver, New J. Chem. 2002, 26, 827-833. ${ }^{[4 b]}$ Z. Freixa, C. J. Bayon, J. Chem. Soc., Dalton Trans. 2001, 2067-2068. ${ }^{[4 c]}$ P. Uriz, E. Fernandez, N. Ruiz, C. Claver, Inorg. Chem. Commun. 2000, 3, 515-519. [4d] Y. Jiang, S. Xue, Z. Li, J. Deng, A. Mi, A. S. C. Chan, Tetrahedron: Asymmetry 1998, 9, 3185-3189. ${ }^{[4 \mathrm{e}]}$ G. J. H. Buisman, L. A. van der Veen, A. Klootwijk, W. G. J. de Lange, P. C. J. Kamer, P. W. N. M. van Leeuwen, D. Vogt, Organometallics 1997, 16, 2929-2939. [4f] J. E. Babin, G. T. Whiteker (to Union Carbide) WO 93/03939 [Chem. Abstr. 1993, 119, 159872 h].

[5] [5a] F. Agbossou-Niedercorn, I. Suisse, Coord. Chem. Rev. 2003, 242, $145-158 .{ }^{[5 b]}$ R. Ewalds, E. B. Eggeling, A. C. Hewat, P. C. J. Kamer, P. W. N. M. van Leeuwen, D. Vogt, Chem. Eur. J. 2000, 6, 1496-1504.

${ }^{[6] ~[6 a] ~ F o r ~ a ~ r e c e n t ~ r e v i e w ~ s e e: ~ J . ~ A n s e l l, ~ M . ~ W i l l s, ~ C h e m . ~ S o c . ~ R e v . ~}$ 2002, 31, 259-268. [6b] E. J. Zijp, J. I. van der Vlugt, M. Fioroni, D. M. Tooke, A. L. Spek, C. Müller, D. Vogt, unpublished work.

[7] [7a] M. T. Reetz, M. Pastó, Tetrahedron Lett. 2000, 41, 3315-3317. ${ }^{[7 b]}$ M. Laly, R. Broussier, B. Gautheron, Tetrahedron Lett. 2000, 41, 1183-1185.

[8] [8a] M. T. Reetz, A. Gosberg, R. Goddard, S.-H. Kyung, Chem. Commun. 1998, 2077-2078. ${ }^{[8 b]}$ C. Claver, E. Fernandez, A. Gillon, K. Heslop, D. J. Hyett, A. Martorell, A. G. Orpen, P. G. Pringle, Chem. Commun. 2000, 961-962. ${ }^{[8 c]}$ A. ZanottiGerosa, C. Malan, D. Herzberg, Org. Lett. 2001, 3, 3687-3690.

[9] M. T. Reetz, D. Moulin, A. Gosberg, Org. Lett. 2001, 3, 4083-4085.

[10] A. Martorell, R. Naasz, B. L. Feringa, P. G. Pringle, Tetrahedron: Asymmetry 2001, 12, 2497-2499.

[11] [11a] D. Selent, K. D. Wiese, D. Röttger, A. Börner, Angew. Chem. Int. Ed. 2000, 39, 1639-1641. ${ }^{[11 b]}$ D. Selent, W. Baumann, R. Kempe, A. Spannenberg, D. Röttger, K. D. Wiese, A. Börner, Organometallics 2003, 22, 4265-4271.

${ }^{[12]}{ }^{[12 a]}$ L. Dahlenburg, Eur. J. Inorg. Chem. 2003, 2733-2747. [12b] L. Dahlenburg, S. Mertel, J. Organomet. Chem. 2001, 630, $221-224 .{ }^{[12 c]}$ L. Dahlenburg, C. Becker, J. Höck, S. Mertel, J. Organomet. Chem. 1998, 564, 155-166.

${ }^{[13]}$ C. Kunze, D. Selent, I. Neda, M. Freytag, P. G. Jones, R. Schmutzler, W. Baumann, A. Börner, Z. Anorg. Allg. Chem. 2002, 628, 779-787.

${ }^{[14]}$ W. Goertz, P. C. J. Kamer, P. W. N. M. van Leeuwen, D. Vogt, Chem. Eur. J. 2001, 7, 1614-1618.

${ }^{[15]}{ }^{[15 a]}$ W. Ahlers, D. Wiebelhaus, R. Paciello, M. Bartsch, R. Baumann, D. Vogt, A. C. Hewat (to BASF AG) WO 02/22261, 2002 [Chem. Abstr. 2002, 136, 249380]. ${ }^{[15 b]}$ J. I. van der Vlugt, A. C. Hewat, S. Neto, R. Sablong, A. M. Mills, M. Lutz, A. L. Spek, C. Müller, D. Vogt, Adv. Synth. Catal. 2004, 346, 993-1003. ${ }^{[15 c]}$ J. I. van der Vlugt, R. Sablong, P. C. M. M. Magusin, A. M. Mills, A. L. Spek, D. Vogt, Organometallics 2004, 23, 3177-3183.

[16] J. I. van der Vlugt, R. Sablong, A. M. Mills, H. Kooijman, A. L. Spek, A. Meetsma, D. Vogt, Dalton Trans. 2003, 4690-4699. 
${ }^{[17]}$ W. Goertz, W. Keim, D. Vogt, U. Engler, M. D. K. Boele, L. A. van der Veen, P. C. J. Kamer, P. W. N. M. van Leeuwen, J. Chem. Soc., Dalton Trans. 1997, 2981-2988.

${ }^{[18]}$ S. Agbossou, M. C. Bonnet, F. Dahan, I. Tkatchenko, Acta Crystallogr., Sect. C 1989, 45, 1149-1152.

${ }^{[19]}$ A. Karaçar, M. Freytag, P. G. Jones, R. Bartsch, R. Schmutzler, Z. Anorg. Allg. Chem. 2001, 627, 1571-1581.

${ }^{[20]}$ M. A. Zuideveld, B. H. G. Swennenhuis, M. D. K. Boele, Y. Guari, G. P. F. van Strijdonck, J. N. H. Reek, P. C. J. Kamer, K. Goubitz, J. Fraanje, M. Lutz, A. L. Spek, P. W. N. M. van Leeuwen, J. Chem. Soc., Dalton Trans. 2002, 2308-2317.

${ }^{[21]}$ J. Yin, S. L. Buchwald, J. Am. Chem. Soc. 2002, 124, 6043-6048.

${ }^{[22] ~ M . ~ K r a n e n b u r g, ~ J . ~ G . ~ P . ~ D e l i s, ~ P . ~ C . ~ J . ~ K a m e r, ~ P . ~ W . ~ N . ~ M . ~ v a n ~}$ Leeuwen, K. Vrieze, N. Veldman, A. L. Spek, K. Goubitz, J. Fraanje, J. Chem. Soc., Dalton Trans. 1997, 1839-1849. [22b] R. J. van Haaren, K. Goubitz, J. Fraanje, G. P. F. van Strijdonck, H. Oevering, B. Coussens, J. N. H. Reek, P. C. J. Kamer, P. W. N. M. van Leeuwen, Inorg. Chem. 2001, 40, 3363-3372.

${ }^{[23]}$ R. van Duren, J. H. J. Huibers, J. I. van der Vlugt, A. M. Mills, A. L. Spek, D. Vogt, unpublished results.

${ }^{[24]}$ R. van Duren, J. I. van der Vlugt, J. Meeuwissen, H. Kooijman, A. L. Spek, D. Vogt, unpublished work.

[25] Typical $\mathrm{Pd}-\mathrm{O}$ distances observed are within the range 2.02-2.14 A, see: ${ }^{[25 a]}$ P. L. Alsters, J. Boersma, W. J. J. Smeets, A. L. Spek, G. van Koten, Organometallics 1993, 12, 1639-1647. ${ }^{[25 b]}$ P. L. Alsters, J. Boersma, H. Kooijman, A. Sicherer-Roetman, A. L. Spek, G. van Koten, Organometallics 1992, 11, 4124-4135.

${ }^{[26]}$ R. Kumar, R. J. Puddephatt, F. R. Fronczek, Inorg. Chem. 1990, 29, 4850-4851.

${ }^{[27]}$ S. P. Shum, S. D. Pastor, G. Rihs, Inorg. Chem. 2002, 41, $127-131$.

${ }^{[28]}$ S. Cserépi-Szücs, J. Bakos, Chem. Commun. 1997, 635-636.

${ }^{[29]}$ G. J. H. Buisman, M. E. Martin, E. J. Vos, A. Klootwijk, P. C. J. Kamer, P. W. N. M. van Leeuwen, Tetrahedron: Asymmetry 1995, 6, 719-738.

${ }^{[30]}$ M. Diéguez, M. M. Pereira, A. M. Masdeu-Bultó, C. Claver, J. C. Bayón, J. Mol. Cat. A: Chem. 1999, 75, 111-122. See also ref. $4 \mathrm{c}$.

[31] C. J. A. Daley, S. H. Bergens, J. Am. Chem. Soc. 2002, 124, 3680-3691.

${ }^{[32]}$ P. Haelg, G. Consiglio, P. Pino, J. Organomet. Chem. 1985, 296, 281-290.
[33] [33a] L. Kollár, J. Bakos, I. Tóth, B. Heil, J. Organomet. Chem. 1988, 350, 277-284. ${ }^{[33 b]}$ L. Kollár, J. P. Sándor, G. Szalontai, J. Mol. Cat. A: Chem. 1991, 67, 191-198. ${ }^{[33 c]}$ L. Kollár, T. Kégl, J. Bakos, J. Organomet. Chem. 1993, 453, 155-158.

${ }^{[34]}$ I. Tóth, I. Guo, B. E. Hanson, Organometallics 1993, 12, $848-852$.

${ }^{[35]}$ H. Buschmann, H. Scharf, N. Hoffmann, P. Esser, Angew. Chem. Int. Ed. Engl. 1991, 30, 477-515.

${ }^{[36]}$ S. W. Breeden, D. J. Cole-Hamilton, D. F. Foster, G. J. Schwarz, M. Wills, Angew. Chem. Int. Ed. 2000, 39, 4106-4108.

${ }^{[37] ~[37 a] ~ W . ~ S . ~ K n o w l e s, ~ M . ~ J . ~ S a b a c k y, ~ B . ~ D . ~ V i n e y a r d, ~ D . ~ J . ~ W e i n-~}$ kauff, J. Am. Chem. Soc. 1975, 97, 2567-2568. [37b] W. S. Knowles, M. J. Sabacky, J. Chem. Soc., Chem. Commun. 1968, 1445-1446.

${ }^{[38]}$ Modified from: A. van Rooij, E. N. Orij, P. C. J. Kamer, P. W. N. M. van Leeuwen, Organometallics 1995, 14, 34-43.

${ }^{[39]}$ With Ni: ${ }^{[39 a]}$ T. J. Anderson, D. A. Vicic, Organometallics 2004, 23, 623-625. ${ }^{[39 b]}$ A. L. Casalnuovo, T. V. RajanBabu, T. A. Ayers, T. H. Warren, J. Am. Chem. Soc. 1994, 116, 9869-9882.

${ }^{[40]}$ With rhodium: ${ }^{40 \mathrm{a}]}$ F. W. Kwok, D. J. Wink, Organometallics 1993, 12, 1954-1959 and references cited therein. ${ }^{[40 \mathrm{~b}]} \mathrm{C}$. Botteghi, S. Paganelli, J. Organomet. Chem. 1991, 417, C41-C45; H.-O. Stühler, Angew. Chem. 1980, 92, 475-476.

${ }^{[41]}$ With Pt: L. E. Crascall, S. A. Litster, A. D. Redhouse, J. L. Spencer, J. Organomet. Chem. 1990, 394, C35-C38. With Pd, see: [41a] F. Bergamin, F. Morandini, A. Turco, Gazz. Chim. Ital. 1990, 120, 57-59. [41b] F. Bergamin, F. Morandini, A. Turco, Gazz. Chim. Ital. 1990, 120, 705-709. ${ }^{[41 c]}$ Y. Becker, J. K. Stille, J. Am. Chem. Soc. 1978, 100, 845-850. ${ }^{[41 \mathrm{~d}]}$ J. S. Roberts, K. J. Klabunde, J. Am. Chem. Soc. 1977, 99, 2509-2515.

${ }^{[42]}$ D. R. Drew, J. R. Doyle, Inorg. Synth. 1972, 13, 52.

${ }^{[43]}$ J. Chatt, L. M. Venanzi, J. Chem. Soc. 1957, 4735-4741.

${ }^{[44]}$ R. Cramer, J. Am. Chem. Soc. 1964, 60, 217-222.

${ }^{[45]}$ J. M. Brown, P. A. Chaloner, A. G. Kent, B. A. Murrer, P. N. Nicholson, D. Parker, P. J. Sidebottom, J. Organomet. Chem. 1981, 216, 263-276.

${ }^{[46]}$ G. M. Sheldrick, SHELXS-97; University of Göttingen, Germany, 1997.

${ }^{[47]}$ G. M. Sheldrick, SHELXL-97; University of Göttingen, Germany, 1997.

${ }^{[48]}$ A. L. Spek, PLATON, A Multi-purpose Crystallographic Tool; Utrecht University, The Netherlands, 2003.

Received February 18, 2004

Early View Article Published Online September 7, 2004 